\title{
Muatan Lokal in Mathematics Learning Process at Schools in Aceh Province
}

\author{
1Mulia Putra, 2Takuya Baba \\ ${ }^{1}$ STKIP Bina Bangsa Meulaboh, Peunaga Cut Ujong, Meureubo, West Aceh Regency, Aceh 23681, Indonesia \\ ${ }^{2}$ Hiroshima University, 1-5-1 Kagamiyama, Higashi-Hiroshima, 739-8529, Japan \\ e-mail: akhiputra@gmail.com
}

\begin{abstract}
Abstrak
Penelitian ini bertujuan untuk mendeskripsikan muatan lokal dan menganalisis proses pembelajaran matematika sekolah di Provinsi Aceh berdasarkan kegiatan matematika universal menurut Bishop. Pengumpulan data dan analisis data dalam penelitian ini menggunakan pendekatan kualitatif. Selain itu, peneliti juga menggunakan pendekatan etnomatematika untuk membuat deskripsi yang runut tentang muatan lokal dan keberadaannya di dalam proses pembelajaran matematika di sekolah-sekolah yang ada di Aceh. Penelitian ini mengungkapkan bahwa kondisi dari muatan lokal di provinsi Aceh masih dalam tahap penyusunan dan pengembangan. Meskipun demikian, pada kenyataannya banyak sekolah di Provinsi Aceh yang sudah mengimplimentasikannya berdasarkan keputusan Menteri Pendidikan dan Kebudayaan Republik Indonesia. Selanjutnya, hasil analisis menunjukkan bahwa keberadaan matematika sudah dapat diidentifikasi secara nyata di dalam materi pembelajaran muatan lokal. Namun, hubungan antara muatan lokal sebagai mata pelajaran dan matematika kelas VII SMP di Provinsi Aceh masih sangat lemah.
\end{abstract}

Kata Kunci: muatan lokal, kegiatan matematika universal Bishop, etnomatematika

\begin{abstract}
This research aims to describe muatan lokal, a subject discussing local culture content in Indonesia, and to analyze mathematics learning process at schools in Aceh Province based on Bishop's universal mathematical activities. The collection and analysis of the data used a qualitative approach. Besides the qualitative approach, we also used an ethnomathematical approach to make a rigorous description of muatan lokal and its existence in the mathematics learning process at the schools. This research found that the current implementation of muatan lokal in Aceh was still in progress of development. In fact, however, many schools have already implemented the subject muatan lokal based on the Indonesian Ministry of Education and Culture's regulation. Furthermore, we could identify the existence of mathematics in the teaching material of muatan lokal subject. However, the connection between both muatan lokal and mathematics as subjects at school is too weak for the VII grade of junior high schools in Aceh.
\end{abstract}

Keywords: muatan lokal, Bishop's universal mathematical activities, ethnomathematics

How to Cite: Putra, M., \& Baba, T. (2018). Muatan Lokal in Mathematics Learning Process at Schools in Aceh Province. International Journal on Emerging Mathematics Education, 2(2), 119-128. http://dx.doi.org/10.12928/ijeme.v2i2.7407

\section{INTRODUCTION}

It is always critical to developing the national identity as a citizen of Indonesia, a country which has diversified ethnic groups and cultures, as well as affection and pride related to cultural identity at the same time. In this sense, it is a prominent issue on how to treat the culture within the school education. In Indonesia, the notion of the content of local culture, hereinafter is called muatan local, was first introduced in 
Indonesia in 1994 as a local content (Shah \& Cardozo, 2014), which was a declaration to deal with the culture within the school education. Since then, it has been referred to in various places and various ways and widened its meaning. Thus, everybody understands its importance, but it continues to be obscure without precise definition. This research tried to observe the implementation of muatan lokal in the schools.

School education is systematized. All activities and subjects are structured together. So, it is inevitable to consider the relationship between the muatan lokal and the subjects. On the other hand, culture spreads into all aspects of school education. Thus, there are two different ways of treatment in the school education. One is to teach a bit of culture in each of school subjects such as language, music, and arts (intersubject-based). In this approach, we can maintain the existing subject framework, but the culture is separated into subjects. The other is to create a new subject and to treat a whole aspect of specific culture within the subject (subject-based). For instance, the subject of ethnic music is taught differently from the other music. Thus, it may lose the broader concept of music. In both approaches, we aim at understanding and conveying the importance of culture. Besides discussion of the subject framework, the muatan lokal also provides materials for teaching subjects. It cannot concretize culture if it does not provide materials. Thus, muatan lokal contains many materials for teaching and learning activity. All these aspects of muatan lokal are presented in Table 1.

Table 1. Meaning of muatan lokal

\begin{tabular}{ll}
\hline \multicolumn{1}{c}{ Aspect } & \multicolumn{1}{c}{ Approach } \\
\hline Subject & Disciplinary (Subject-based) \\
& Interdisciplinary (inter-subject-based) \\
Teaching materials & Culture content \\
& Learning context \\
\hline
\end{tabular}

Mathematics is a universal science that promotes the development of technology (Revina \& Leung, 2018) and is usually regarded as an abstract subject (Hidayah et al., 2018) because the nature of mathematics is usually independent towards culture. Anywhere in the world, the answer to $1+1$ is always the same. However, D'Ambrosio (1985) proposed the notion of ethnomathematics by referring to the culturalmathematical activity. Ascher (1991) provided a lot of ethnomathematical examples and substantiated the notion of ethnomathematics. Bishop (1991) pointed out an essential point of a universality of ethnomathematics, which seems to have cultural diversity. His point is that all cultures have six universal mathematical activities such as counting, measuring, locating, explaining, designing, and playing regardless its different appearances. It expresses both cultural diversity and universality of mathematics.

Mathematics is one of the main subjects in the Indonesian school education. Moreover, it is usually regarded as being far from culture. Because of its abstract nature, students view mathematics as a difficult subject to learn. Ethnomathematics may provide a new possibility of the cultural entrance to the universality of mathematics. Thus, it is the first step to concretize the mathematics education through muatan lokal and to systematize its treatment of culture within the mathematics education. When ethnomathematics is taken up, it is necessary to not only understand ethnomathematics but also its cultural background. If the cultural activity is taken up separately from the whole culture, we may miss understand the intention of the

IJEME, Vol. 2, No. 2, September 2018, 119-128. 
activity and thus may take the risk of disgracing the culture. Therefore, the example is made of the area which is well-known to the author, Aceh Province.

Indonesia has many islands and various tribes in the different provinces. There is a unique subject or material that has been transformed rapidly as the way to create awareness towards cultural values. It is called muatan lokal (Musanna, 2009). The transformation of muatan lokal itself happens because the dynamic revision of the education curriculum in Indonesia which bring the tendency of muatan lokal to change in a new form to adapt to the new curriculum. Moreover, the muatan lokal can be considered as an aspect that can be used to promote the social understanding in Indonesia (Civitillo et al., 2017). The complexity of muatan local, however, becomes a problem in the implementation because it can be both independent that has nothing to do with any subject and attached to all subjects.

Recently, Indonesia applies the 2013 Curriculum. In fact, compared to the previous curriculum, there are four elements of change in the current curriculum. They are (1) graduate competence standard, (2) content standard, (3) learning process standard, and (4) assessment standard. This condition impacts to the muatan lokal and the mathematics curriculum in Indonesia including Aceh Province. However, at least there is one similarity between the previous curriculum and the new curriculum in Indonesia. It is that both muatan lokal and mathematics still exist in the school curriculum. The problem which appears, in this case, is that the ability of a teacher to explore and to prepare muatan lokal material and teacher's effort to integrate muatan lokal in the other subject including mathematics is still low (Adlim et al., 2016).

Moreover, regarding integrated learning between muatan lokal and mathematics, the tendency to ignore muatan lokal and mathematics to be incorporated together already happen in Indonesia including Aceh. It can be seen from the Article 4 of the Indonesian Ministry of Education and Culture Regulation number $79 / 2014$ which states that the term of muatan lokal itself could be integrated with others subject such as cultural art, craft, and physical education (MoEC, 2014). The trend to look mathematics as a "full of calculation" subject also restricts teacher to explore innovative learning practice (Istiandaru et al., 2014) or to integrate muatan lokal and mathematics together, besides nowadays, mathematics has been already expressed in a broad view which includes arithmetic; classifying, ordering, modeling and mathematical practice as a cultural product (Balamurugan, 2015). Thus, grasping more information and description related to muatan lokal and its existence in mathematics learning process is very important as the reason to make muatan lokal more beneficial for students primarily in mathematics learning process.

\section{Research Question}

This research raises a question to what extent the muatan lokal can be described in the mathematics learning process at schools in Aceh Province.

\section{Objective}

This paper aims to describe the implementation of muatan lokal in Aceh Province and to analyze the mathematics learning process based on Bishop's universal mathematical activities. 


\section{Literature Review on Muatan Lokal}

Based on history, before entering the formal education in Indonesia, parents have taught their children the concepts and teachings of muatan lokal through trial and error based on their experiences. This muatan lokal teaching aims to make the children become independent in their life (Basari, 2014). As time goes on, the term for muatan lokal is defined variously. For example, muatan lokal is a material in the educational unit containing the content and learning process about the potential and local uniqueness that is intended to form students' understanding of the potential in the area where they lived (MoE, 2013). However, after the revision, muatan lokal is a material or subject in the educational unit containing the content and learning process about the potential and local uniqueness that is intended to form students' understanding of the benefits and wisdom in the area where they lived (MoEC, 2014). Comparing both definitions, previously, muatan lokal only study material, but a new term for muatan lokal have been changed, it is not only study material but also can be formed into a subject. Therefore, in the Indonesian students' report, some muatan lokals are categorized as subjects. In every province, muatan lokal has been implemented in various ways, and it depends on the cultural characteristics of the province. In order to avoid bias in this study, muatan lokal is defined as material in the formal or informal educational unit containing the content and learning process about the potential and local uniqueness that is intended to form learner's understanding toward the benefits and wisdom in the area where they lived.

Aceh Province as a part of Indonesia also implements muatan lokal in the school with various subjects and materials. Based on unstructured interviews towards some schools in Aceh through a messenger, muatan lokal in Aceh can be formed in language studies such as Arabic and English. The other is memorizing the verses of Alquran. In a particular case, mathematics also become as material in muatan lokal. However, in a rural area, the condition on muatan lokal was implemented without the syllabi which means that there is no guidance for implementation (Adlim et al., 2016).

\section{Ethnomathematics and Bishop's Universal Mathematical Activities}

The term for ethnomathematics was first used by D'Ambrosio in many of his writings and speeches to explain the relationship between cultural practices concerning the development and the application of mathematical ideas (ArismendiPardi, 2001). D'Ambrosio (1985) stated that there is a need of space for the curriculum to let ethnomathematics come in. Hence the society realizes that mathematics is not only for western countries but also for whole humankind in the world. This statement aims to say that the present generation needs to prepare for the next generation who has a better view towards mathematics as the way to create sustainable peace of the world in the future (D'Ambrosio, 2003). In the field of research, ethnomathematics has been developed from a connection to race and origin to intercultural learning. Ethnomathematics is applicable within any learning context with various social and cultural diversities of all children and their background. Therefore, the program of ethnomathematics needs to be supported (Abdullah, 2017; Powell \& Frankenstein, 1997).

The past two decades have seen ethnomathematics and multicultural approaches become much more widespread even to the extent of becoming commonplace (Francois, 2012). Multiculturalism has become a part of many national curriculum (Balamurugan, 2015). For example, in Brazil, the use of Bakairi body painting in Bakairi Schools facilitates the comprehension of spatial relations as form,

IJEME, Vol. 2, No. 2, September 2018, 119-128. 
texture, and symmetry, which are excellent for the construction and the systematization of geometrical knowledge by allowing students to experience academic mathematical language through cultural lenses (Rosa \& Orey, 2016). Another example, Zhang \& Zhang (2010) stated that China got some enlightenment for high school mathematics curriculum reform based on Mozambican peasant build houses in Africa, the knowledge involved in the two methods for the construction of the quadrilateral bases of traditional houses can be related deeply to vector. Both examples consider as ethnomathematics because there is at least one universal mathematical activity from each culture that appears which is designing. It is based on Bishop's universal mathematical activities which are counting, locating, measuring, designing, playing, and explaining (Bishop, 1991).

The following explanation describes the meaning of each activity.

1. Counting, this is a way of distinguishing, tallying or apprehending quantities of objects or events which may be perceptually or conceptually possible counting. The counting of events, in contrast to objects, underlies of the understanding of prediction, probability and chance and representation of large numbers of events stimulates the need for a system, for symbols and representation such as frequency charts and graphs.

2. Locating emphasizes the spatial geometry of position and controlled movement, and undoubtedly should not be a mere pencil-on-paper exercise. The concepts here derived from activities set within the child's immediate and accessible environment, and from coding and symbolizing the results of those activities in various ways.

3. Measuring is concerned predominantly with comparing things according to a shared quality, and develops through paired comparisons to many comparisons, through available units to standardized units and systems of units. The notion of quality as a 'continuous' quantity is there (as opposed to the discrete, in counting) and therefore the problems, rather than the 'how many' problems which provoke counting activities.

4. Designing is the activity which probably makes the most visible and immediate perceptual connections with the environment. One sees shapes around, and it is very 'natural' to inquire about them mainly in the increasingly manufactured world which uses many geometrically interesting shapes.

5. Playing is a mathematically significant activity. The progression is from 'games' to 'mathematical games' to 'mathematics as a game' and the aesthetics of these are every bit as important in the child's cultural development as are their cognitive significance.

6. Explaining, the aim of including this set of concepts in the curriculum is to focus this activity directly on what we can call the meta-conceptual level. To a certain extent this is also the case with 'playing' as we saw, but here one can engage the children directly in the way Mathematics explains, in the sort of 'answers' one can obtain to Mathematical questions, in the kinds of questions themselves and power (and limitation) of Mathematical explaining.

\section{RESEARCH METHOD}

The qualitative approach has been used to gain and analyze the data. This research approach considers as the best way to describe muatan lokal in Aceh Province and its existence in mathematics learning process at school because the qualitative design allows the researcher to focus on insight, discovery, and 
interpretation rather than hypothesis testing (Merriam, 1998). Besides, for exploring a phenomenon, a qualitative approach is vital (Creswell, 2014).

Since muatan lokal is related to culture and exploring its existence in mathematics learning process is the focus on this research, bring ethno-mathematical approach also essential as the reason to make a rigorous description about muatan lokal and its existence in mathematics learning process at school in Aceh. Furthermore, six universal mathematical activities by Bishop will be the key terms in exploring the existence of muatan lokal in mathematics learning process. Analysis of documents from teacher's and student's mathematics book grade VII Junior High School in Aceh (As'ari et al., 2016) will be the primary data resources, besides there is also a snapshot of student's report as the additional document.

\section{RESULTS AND DISCUSSION Muatan Lokal in Aceh Province}

The term for muatan lokal in Indonesia is something that already well known in Indonesian education curriculum since 1994 and each province implements this different subject depend on local history, culture and industry as one of the ways to improve education quality in Indonesia (Nakaya, 2015). However, muatan lokal also brings some dichotomy for teachers. On the one hand, it means as material and on the other hand, it means as the subject which needs core competence and basic competence. Therefore, MoEC (2014) revised the meaning of muatan lokal to be both materials and subjects.

Furthermore, regarding muatan lokal as material in a learning process, it should be integrated with other subjects such as cultural art, craft, and physical education. It is based on the Article 4(3) of the regulation. It also means that there is a possibility for muatan lokal to be infiltrated in other subjects such as mathematics if it fits with the context. In this case, muatan lokal adapts to the condition of mathematics material.

Right now, muatan lokal can be found only as a subject in the school which has competence standard, syllabus, and textbook. For example in Aceh province, generally, there are three subjects for muatan lokal which are cultural art (CA), physical education, sports and health (PESH), and craft (CR). It based on a student's report from one of the schools in Aceh as shown in Figure 1.

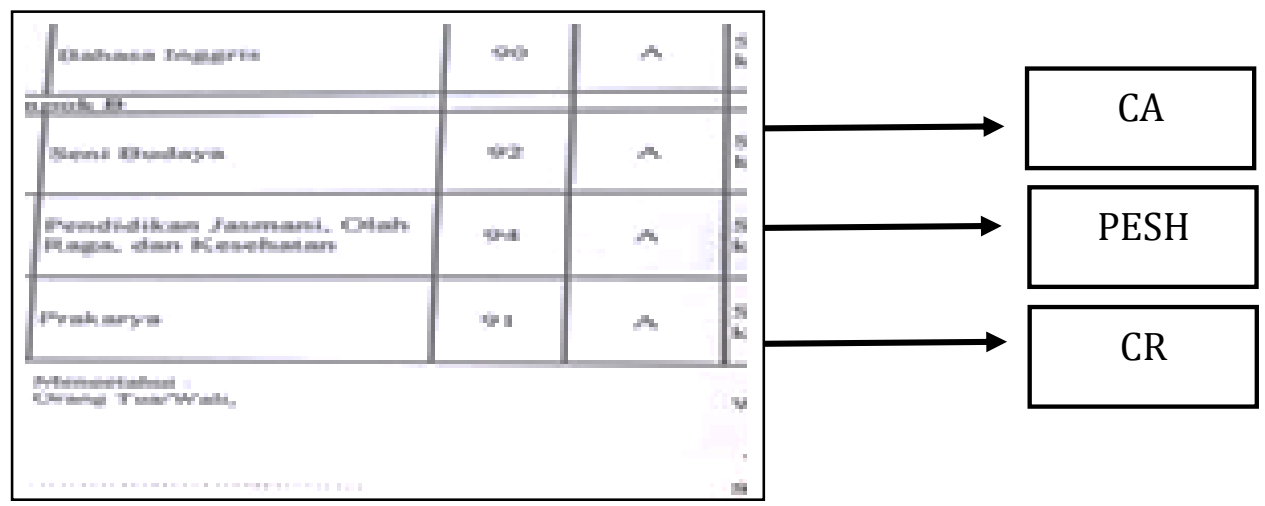

Figure 1. Muatan lokal subjects in Aceh Province

In Aceh and other provinces in Indonesia, muatan lokal's book is provided by the government since three of these subjects become a general muatan lokal in Indonesia which are cultural art, craft, and physical education, sports and health. The book itself consists of the book for teachers and book for students. Hence, considering this

IJEME, Vol. 2, No. 2, September 2018, 119-128. 
general muatan lokal in Aceh, some practitioners argue the need for muatan lokal which focus on life skill (Basari, 2014). The need for muatan lokal to be composed directly by the education department in Aceh since almost there is no subject introduce or explain specifically about local content in Aceh (Musanna, 2009). Finally, it shows that the condition of muatan lokal in Aceh province still on the way to be composed and developed, although, in reality, many schools already implemented muatan lokal based on Ministry of Education and Culture's regulation.

\section{The Existence of Muatan Lokal in Mathematics Learning Process at School}

Since there is a possibility to integrate muatan lokal in mathematics learning process or vice versa, the way to describe muatan lokal's existences in mathematics learning process is something difficult to do. However, through analyzing a part of mathematics textbooks by considering six universal mathematics activities by Bishop (1991), some of the muatan lokal materials exist in mathematics learning process.

Three books used in this research to know the existence of muatan lokal in mathematics learning process. They are culture art teacher's book, mathematics teacher's book and student's book from Junior High School grade VII second semester focus on quadrilateral and triangle topic. At the beginning of the topic, in the mathematics teacher's book, there is a picture as shown in Figure 2.

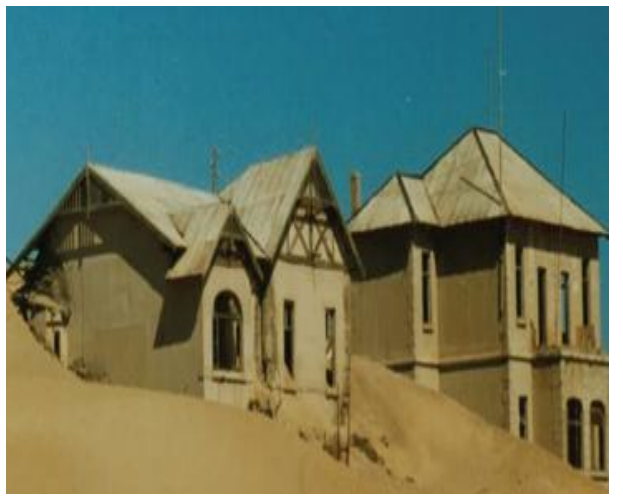

Perhatikan dengan teliti pada gambar di atas! Jika kita amati pada gambar tersebut, sebagian besar bahan dasarnya terdiri dari bangun segi empat dan segitiga. Adakah bangun lain yang bahan dasarnya terdiri dari bangun segi empat dan segitiga? Coba amatilah lingkungan sekitarmu. Bentuk bangun manakah yang ada pada benda-benda di sekitarmu? Apakah setiap bangun yang kalian temukan sebagian besar terdiri dari bangun segitiga dan segi empat? Untuk memahami lebih jauh mengenai segi empat dan segitiga pelajarilah uraian bab ini dengan saksama.

Figure 2. Content emerged in the teacher's book

At a glance, there is no item of muatan lokal appear in teacher book, rather than a picture of the old house that is not from Indonesia. However, regarding narration besides the picture, it states: Look carefully at the picture! If we look at the picture, most of the basic material consists of a quadrilateral and triangle shapes. Is there any other building whose basic material consists of quadrilateral and triangle shapes? Try to observe your surroundings! What is the shape of the things you see? Is every building you find mostly consists of quadrilateral and triangle shape? To understand more about quadrilateral and triangle, you need to learn this chapter thoroughly.

Based on the translation above, there are at least two universal mathematical activities that a teacher intends to ask from students which are:

1. Locating, it can be found from the sentence "Look carefully at the picture!, and "Is there any other building whose basic material consists of a quadrilateral and triangle shape?"

2. Designing, it happens once students think about quadrilateral and triangle and try to clarify which one is quadrilateral or triangle from the building.

Indeed, these two activities are universal mathematics activities which leads to the important idea of shape (Bishop, 1991). 
Moreover, analyzing the sentence "Try to observe your surroundings" gives an opportunity to infiltrate muatan lokal in this material since muatan lokal itself close to student's daily life. Therefore, in student's textbooks, such kind of the following picture appear, and some of those pictures show the Indonesia culture objects, namely ketupat (traditional sticky rice), kite, door, and roof of a building as shown in Figure 3.
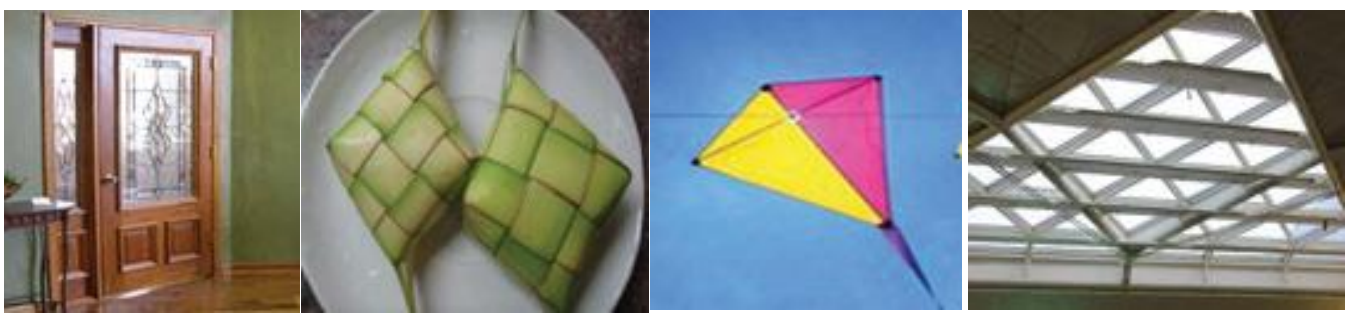

Figure 3. Content which emerged in the student's textbook

Furthermore, we bring both findings and material of muatan lokal from the culture art books grade VII. It clearly states that students should know the need for quadrilateral and triangle aspect because the material consists of a geometry pattern in decorating an artistic work which is quadrilateral and triangle as shown in Figure 4.

C. Pola Ragam Hias

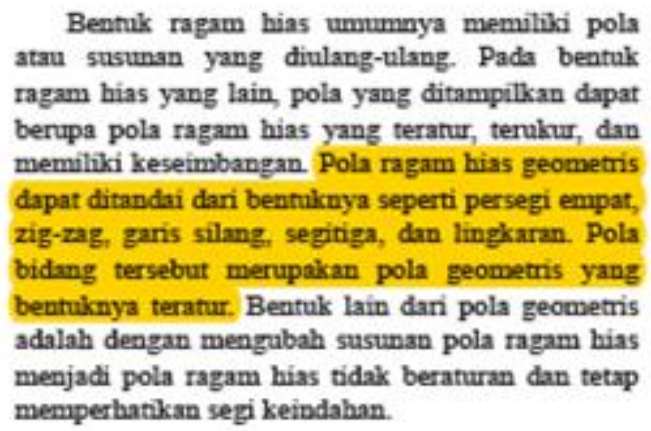

Figure 4. The need of students to know quadrilateral and triangle in muatan lokal

The translation of the yellow marked sentence is as follows: "Geometrical pattern can be marked out through its shape like quadrilateral, zig-zag line, cross-line, triangle, and circle. Those patterns are regular geometric patterns".

Even though the existence of mathematics in muatan lokal based teaching material is real, unfortunately, the connection between muatan lokal as a subject based and mathematics at school level is very weak. It is because the notion of mathematics in muatan lokal as subject-based do not being stated explicitly. Overall, by using these findings, it can be concluded that muatan lokal as teaching material appear in mathematics textbook for grade VII or vice versa which lead to muatan lokal existence in mathematics learning process at school. In fact, descriptively both muatan lokal and mathematics at school grade VII have a weak connection. However, the probability of integrating them is a necessity. Therefore, further analysis is compulsory throughout the school in Indonesia including Aceh. 


\section{CONCLUSION}

The condition of muatan lokal in Aceh province still on the way to be composed and developed, although, in reality, many schools already implemented muatan lokal based on Ministry of Education and Culture's regulation. To go further, related to the existence of muatan lokal in mathematics learning process at school or vice versa, both of them still has a weak connection, but the possibility to integrate them considered as a necessity for better mathematics education in the classroom.

\section{REFERENCES}

Abdullah, A. S. (2017). Ethnomathematics in Perspective of Sundanese Culture. Journal on Mathematics Education, 8(1), 1-16.

Adlim, M., Gusti, H., \& Zulfadli, Z. (2016). Permasalahan dan Solusi Pendidikan di Daerah Kepulauan: Studi Kasus di SMA Negeri 1 Pulau Aceh, Kabupaten Aceh Besar. Jurnal Pencerahan, 10(2), 48-61.

Arismendi-Pardi, E. J. (2001). Ethnomathematics: An Alternative Approach to the Practice of Teaching and Learning. Washington: Edmonds Community College.

As'ari, A. R., Tohir, M., Valentino, E., Imron, Z., \& Taufiq, I. (2016). Buku Guru Matematika SMP/MTs Kelas VII (Edisi Revisi). Jakarta: Kementerian Pendidikan dan Kebudayaan.

Ascher, M. (1991). Ethnomathematics: A Multicultural View of Mathematical Ideas. California: Brooks/Cole Publishing Company.

Balamurugan, M. (2015). Ethnomathematics: An Approach for Learning Mathematics from Multicultural Perspectives. International Journal of Modern Research and Reviews, 3(6), 716-720.

Basari, A. (2014). Penguatan Kurikulum Muatan Lokal dalam Pembelajaran di Sekolah Dasar. Prosiding Ilmu Pendidikan, 1(1), 17-26.

Bishop, A. J. (1991). Mathematical Enculturation: A Cultural Perspective on Mathematics Education. Dordrecht: Kluwer Academic Publishers.

Civitillo, S., Schachner, M., Juang, L., van de Vijver, F. J., Handrick, A., \& Noack, P. (2017). Towards a Better Understanding of Cultural Diversity Approaches at School: A Multi-Informant and Mixed-Methods Study.Learning, Culture and Social Interaction, 12, 1-14.

Creswell, J. W. (2014). Research Design: Qualitative, Quantitative, and Mixed Methods Approaches. California: SAGE Publications.

D'Ambrosio, U. (1985). Ethnomathematics and Its Place in the History and Pedagogy of Mathematics. For the Learning of Mathematics, 5(1), 44-48.

D'Ambrosio, U. (2003). Stakes in Mathematics Education for the Societies of Today and Tomorrow. In D. Coray, et al. (Eds.), Monographie de L'Enseignment Mathèmatique: One Hundred Years of L'Enseignment Mathèmatique: Moments of Mathematics Education in the Twentieth Century (pp. 301-316). Genève: L'Enseignement Mathematique.

Francois, K. (2012). Ethnomathematics in a European Context: Towards an Enriched Meaning of Ethnomathematics. Journal of Mathematics and Culture, 6(1), 191208. 
Hidayah, I. Dwijanto, \& Istiandaru, A. (2018). Manipulatives and Question Series for Elementary School Mathematics Teaching on Solid Geometry. International Journal of Instruction, 11(3), 649-662.

Istiandaru, A., Wardono, \& Mulyono. (2014). PBL Pendekatan Realistik Saintifik dan Asesmen PISA Untuk Meningkatkan Kemampuan Literasi Matematika. Unnes Journal of Mathematics Education Research, 3(2), 64-71.

Merriam, S. B. (1998). Qualitative Research and Case Study Application in Education. San Francisco: Josey Bass Publishers.

Musanna, A. (2009). Pengembangan Kurikulum Muatan Lokal dalam Konteks Pendidikan di Aceh. Jurnal Penelitian, 10(2), 1-12.

Nakaya, A. (2015). Community-Based Education to Improve Quality of Life: Case Study of Muatan Lokal in Indonesia. Proceeding of the First International Conference on Research Innovation \& Commercialization for a Better Life. Semarang: LP2M UNNES.

MOEC. (2014). Regulation of the Indonesian Ministry of Education and Culture number 79 of 2014 about the Muatan Lokal of the 2013 Curriculum. Jakarta: Ministry of Education and Culture.

Powell, A. B., \& Frankenstein, M. (1997). Ethnomathematics: Challenging Eurocentrism in Mathematics Education. New York: State University of New York.

Revina, S., \& Leung, F. K. S. (2018). Educational Borrowing and Mathematics Curriculum: Realistic Mathematics Education in the Dutch and Indonesian Primary Curriculum. International Journal on Emerging Mathematics Education, 2(1), 1-16.

Rosa, M., \& Orey, D. C. (2016). Humanizing Mathematics through Ethnomodelling. Journal of Humanistic Mathematics, 6(2), 3-22.

Shah, R., \& Cardozo, M. L. (2014). Education and Social Change in Post-Conflict and Post-Disaster Aceh, Indonesia. International Journal of Educational Development, 38, 2-12.

Zhang, W., \& Zhang, Q. (2010). Ethnomathematics and Its Integration within the Mathematics Curriculum. Journal of Mathematics Education, 3(1), 151-157. 